\title{
Pengaruh Beban Kerja, Klien Baru, Dan Ukuran Klien Terhadap Defisiensi Audit
}

\author{
Budhi Setiya Yoga ${ }^{1}$ \\ Agung Dinarjito ${ }^{2}$ \\ 1,2Politeknik Keuangan Negara STAN Jakarta, Indonesia \\ email:bsyoga1@gmail.com
}

DOI: https://doi.org/10.24843/JIAB.2019.v14.i01.p09

\begin{abstract}
ABSTRAK
Jurnal Ilmiah Akuntansi dan Bisnis (JIAB)

https://ojs.unud.ac.id/index.php/jiab/ user/profile

Volume 14

Nomor 1

Januari 2019

Halaman 95-105

p-ISSN 2302-514X

e-ISSN $\underline{2303-1018}$

\section{INFORMASI ARTIKEL}

Tanggal masuk:

07 Nopember 2018

Tanggal revisi:

26 Desember 2018

Tanggal diterima:

02 Januari 2019

Penelitian ini bertujuan menguji apakah beban kerja akuntan publik, klien baru, dan ukuran klien mempengaruhi defisiensi audit yang dilakukan oleh akuntan publik yang diidentifikasi oleh Pusat Pembinaan Profesi Keuangan (PPPK), Kementerian Keuangan. PPPK diberikan kewenangan untuk memastikan bahwa audit yang dilakukan oleh akuntan publik telah sesuai dengan standar yang berlaku. Penelitian ini merupakan penelitian kuantitatif dengan teknik analisis regresi linear berganda menggunakan data akuntan publik yang diperiksa oleh PPPK tahun 2013 sampai 2016. Hasil penelitian menunjukkan hanya ukuran klien mempengaruhi defisiensi audit yang diidentifikasi oleh PPPK. Penelitian dapat menjadi masukan bagi akuntan publik agar memberikan perhatian yang tepat atas audit klien-klien besar serta diharapkan dapat membantu PPPK dalam menentukan sampel pemeriksaan terhadap akuntan publik setiap tahunnya.

Kata Kunci: Audit, defisiensi audit, PPPK, akuntan publik

\section{Effects of Workload, New Clients, and Client Size on Audit Deficiencies \\ ABSTRACT}

This study aims to examine whether public accountants' workload, new clients, and size of clients influence the occurrence of audit deficiencies conducted by public accountants on the basis of the data collected by the Finance Professions Supervisory Centre (PPPK), Ministry of Finance. PPPK is given the authority to ensure that the audits carried out by public accountants are in accordance with applicable standards. This is a quantitative research using multiple linear regression analysis of public accountants' data examined by PPPK from 2013 to 2016. Test results show that only the client size affects the audit deficiencies identified by PPPK in a positive direction. This research is expected to be a resource for public accountants to give proper attention during audits of large clients and help PPPK in determining the examination samples of public accountants each year.

Keywords: Audit, audit deficiency, PPPK, public accountant
\end{abstract}

\section{PENDAHULUAN}

Audit laporan keuangan merupakan jasa asurans yang berguna untuk menjamin keandalan informasi dalam laporan keuangan suatu perusahaan. Audit atas laporan keuangan berguna untuk meningkatkan derajat keyakinan pengguna laporan keuangan bahwa laporan keuangan secara keseluruhan bebas dari kesalahan penyajian material baik yang disebabkan oleh kesalahan maupun kecurangan (Institut Akuntan Publik Indonesia, 2013). Untuk mencapai tujuan tersebut, maka audit harus dilaksanakan secara berkualitas.

Fakta sejarah membuktikan bahwa kegagalan dalam melaksanakan audit berkualitas dapat membawa petaka bagi perekonomian suatu bangsa. Salah satu contoh adalah kasus Enron dan Kantor 
Akuntan Publik (KAP) Arthur Andersen di Amerika yang terjadi pada tahun 2001. Adanya skandal antara KAP Arthur Andersen dan manajemen Enron tersebut telah membawa dampak buruk bagi perekonomian di Amerika pada saat itu. Oleh karena itu, berbagai upaya kemudian dilakukan untuk mencegah terjadinya kegagalan pelaksanaan audit yang berkualitas sebagaimana kasus Enron tersebut.

Upaya tersebut antara lain dilakukan dengan mengeluarkan Sarbanes Oxley Act (SOX) pada tahun 2002. Salah satu keputusan penting yang tercantum dalam Sarbanes Oxley Act adalah pembentukan Public Company Accounting Oversight Board (PCAOB) yang memiliki tugas utama melakukan pengawasan terhadap auditor dalam rangka mencegah kasus serupa Enron terulang kembali (Kang, Farag, Hurt, \& Wyrick, 2014). Pengawasan oleh PCAOB tersebut bertujuan untuk melindungi kepentingan investor dan masyarakat umum dalam penyiapan laporan audit yang informatif, wajar, dan independen oleh auditor (Public Company Accounting Oversight Board, 2006). Pengawasan yang dilakukan oleh PCAOB didesain untuk mengidentifikasi dan menemukan defisiensi terkait dengan bagaimana akuntan publik (AP) dan KAP melaksanakan auditnya (Public Company Accounting Oversight Board, 2017). Public Company Accounting Oversight Board (2016) menyatakan bahwa defisiensi audit meliputi kegagalan AP dan KAP untuk mengidentifikasi atau menyatakan dengan tepat kesalahan dalam laporan keuangan, termasuk kegagalan untuk memenuhi persyaratan pengungkapan, serta kegagalan AP dan KAP untuk melaksanakan atau melaksanakan dengan memadai, prosedur audit tertentu yang diperlukan.

Otoritas yang bertugas untuk mendeteksi dan mencegah terjadinya defisiensi audit di Indonesia antara lain dilaksanakan oleh Pusat Pembinaan Profesi Keuangan (PPPK), Kementerian Keuangan. PPPK melakukan pembinaan dan pengawasan terhadap profesi keuangan yang salah satunya meliputi profesi akuntan publik. Hal tersebut sebagaimana tercantum dalam pasal 2023 Peraturan Menteri Keuangan (PMK) Nomor 234/PMK.01/ 2015 tentang Organisasi dan Tata Kerja Kementerian Keuangan. Pengawasan terhadap AP dan KAP secara lebih khusus dilaksanakan oleh Bidang Pemeriksaan Profesi Akuntansi (PPA) PPPK melalui pemeriksaan berkala dan pemeriksaan sewaktuwaktu.

Berdasarkan Laporan Hasil Pemeriksaan (LHP) PPPK tahun 2013 sampai dengan tahun 2016, jasa audit yang diberikan oleh akuntan pulik di Indonesia belum sepenuhnya bebas dari defisiensi audit. Data Laporan Hasil Pemeriksaan berkala terhadap akuntan publik terkait aspek audit umum atas laporan keuangan dapat dilihat pada Tabel 1 .

Tabel 1. Data LHP PPPK Tahun 2013-2016

\begin{tabular}{lcccc}
\hline Tahun Pemeriksaan & 2013 & 2014 & 2015 & 2016 \\
\hline Jumlah AP diperiksa & 17 & 39 & 70 & 92 \\
Jumlah AP melanggar & 16 & 37 & 61 & 89 \\
Jumlah AP taat (tidak ada temuan) & 1 & 2 & 9 & 3 \\
Jumlah temuan (defisiensi audit) & 56 & 106 & 207 & 499 \\
\hline
\end{tabular}

Sumber: Data diolah, 2018

Berdasarkan Tabel 1 dapat dilihat bahwa defisiensi audit berupa pelanggaran terhadap Standar Profesional Akuntan Publik (SPAP) yang diidentifikasi PPPK jumlahnya sangat banyak secara relatif meningkat dari tahun ke tahun sesuai dengan peningkatan jumlah AP yang diperiksa dengan pola yang tidak jelas. Oleh karena itu, perlu diteliti penyebab banyaknya defisiensi audit tersebut sehingga dapat dicarikan solusi yang tepat untuk mencegah berulangnya defisiensi serupa. Disamping itu, hasil penelitian ini dapat digunakan untuk memberikan tambahan pedoman bagi Pusat Pembinaan Profesi Keuangan dalam menentukan prioritas pemeriksaan AP sesuai dengan karakteristik yang teridentifikasi terkait dengan risiko terjadinya defisiensi audit. Hasil penelitian ini juga dapat dijadikan acuan bagi AP dan KAP untuk melakukan perbaikan kualitas auditnya yaitu dengan mengetahui karakteristik terjadinya defisiensi audit, maka AP dan KAP dapat memfokuskan perhatiannya pada masalah tersebut.

Penelitian ini merupakan penelitian yang menguji pengaruh beban kerja akuntan publik, klien baru, dan ukuran klien secara langsung terhadap defisiensi audit yang diidentifikasi PPPK. Penggunaan variabel defisiensi audit yang diidentifikasi PPPK memberikan 
informasi penting tentang gambaran kinerja akuntan publik yang diperiksa dari sisi regulator selaku pihak yang independen.

Penelitian sebelumnya terkait dengan beban kerja telah dilakukan diantaranya oleh Setiawan W \& Fitriany (2011). Penelitian tersebut melihat pengaruh beban kerja terhadap kualitas audit dalam level KAP. Berbeda dengan penelitian tersebut, penelitian ini menggunakan pengukuran beban kerja dalam level AP dengan melihat jumlah klien yang riil ditangani oleh AP sehingga selaras dengan pengukuran variabel defisiensi audit yang juga dalam level AP. Namun, hal ini penting untuk diteliti diantaranya karena klien baru memerlukan pengujian yang lebih kompleks dibandingkan dengan klien berulang misalnya karena diharuskan untuk melakukan pengujian saldo awal (Institut Akuntan Publik Indonesia, 2013b). Selanjutnya, penelitian terkait dengan ukuran klien diantaranya dilakukan oleh Kafabih \& Adiwibowo (2017). Namun, pengaruh ukuran klien dalam penelitian tersebut dihubungkan dengan kualitas audit yang diukur dengan modal kerja abnormal akrual.

Teori yang mendasari penelitian ini adalah teori keagenan. Jensen \& Meckling (1976) mendefinisikan hubungan keagenan sebagai kontrak antara satu atau lebih orang (prinsipal) dengan pihak lain (agen) untuk melaksanakan kepentingan prinsipal. Dalam hal ini agen dan prinsipal memiliki kecenderungan untuk memaksimalkan kepentingannya masing-masing (Jensen \& Meckling, 1976). Seharusnya agen bertindak sesuai dengan kepentingan prinsipal. Namun, dalam kenyataannya agen dapat bertindak untuk memaksimalkan kepentingannya sendiri. Akibatnya muncul masalah keagenan dimana agen tidak bertindak untuk kepentingan terbaik prinsipal. Hal ini dikarenakan adanya pemisahan antara kepemilikan dan kontrol (Jensen \& Meckling, 1976), dimana prinsipal selaku pemilik tidak memiliki kontrol atas sumber daya. Sebaliknya agenlah yang memiliki kontrol atas sumber daya. Dengan demikian terjadi asimetri informasi antara prinsipal dan agen yang mana agen memiliki informasi lebih banyak dibandingkan dengan prinsipal. Dalam kondisi ini, terdapat kecenderungan agen untuk memanipulasi laporan keuangannya dengan memberikan informasi yang salah atau tidak lengkap.

Penelitian terkait pengaruh beban kerja terhadap defisiensi audit diantaranya dilakukan oleh Chang, Luo, \& Zhou (2017) yang bertujuan untuk melihat pengaruh beban kerja terhadap defisiensi audit yang diidentifikasi PCAOB. Ukuran beban kerja dalam penelitian tersebut menggunakan rasio klien terhadap partner dan rasio klien terhadap staf profesional. Adapun defisiensi audit diukur dengan temuan hasil pemeriksaan PCAOB. Hasil penelitian tersebut menyatakan bahwa beban kerja berpengaruh positif terhadap terjadinya defisiensi audit. Artinya, semakin tinggi beban kerja, maka defisiensi audit yang ditemukan PCAOB semakin banyak.

Penelitian lain terkait dengan beban kerja dilakukan oleh (Setiawan \& Fitriany, 2011). Penelitian ini menggunakan akrual diskresioner sebagai pengukuran kualitas audit dan empat pengukuran workload (jumlah klien dibagi jumlah partner, jumlah revenue dibagi jumlah partner, jumlah revenue dibagi jumlah staf auditor, dan jumlah klien dibagi jumlah staf auditor) penelitian tersebut menyimpulkan bahwa beban kerja berpengaruh negatif terhadap kualitas audit yang artinya semakin tinggi beban kerja, maka kualitas audit akan menjadi semakin buruk sehingga meningkatkan potensi terjadinya defisiensi audit. Sehubungan dengan itu, Setiawan \& Fitriany (2011) menyatakan bahwa beban kerja dapat diketahui dengan melihat jumlah klien yang harus ditangani seorang auditor atau terbatasnya waktu yang tersedia untuk melaksanakan proses audit. Oleh karena itu, hipotesis pertama penelitian ini adalah:

$\mathrm{H}_{1}$ : Beban kerja akuntan publik berpengaruh terhadap defisiensi audit yang diidentifikasi PPPK.

Penelitian terkait dengan klien baru (perikatan audit tahun pertama) dilakukan oleh Liu, Xie, Chang, \& Forgione (2017) yang meneliti hubungan antara klien baru, kualitas audit, dan spesialis auditor di Taiwan. Dalam penelitian tersebut, kualitas audit diukur dengan menggunakan akrual diskresioner. Hasil dari penelitian tersebut menyatakan bahwa keputusan penerimaan klien baru merupakan hal kritis bagi auditor. Kualitas audit akan dipengaruhi secara negatif oleh adanya penerimaan klien baru bagi auditor (Liu et al., 2017) yang artinya adanya penerimaan klien baru akan menurunkan kualitas audit sehingga berpotensi menimbulkan defisiensi audit yang lebih banyak. Hal ini disebabkan terbatasnya pengetahuan auditor terhadap kondisi keuangan dan operasi klien baru sehingga auditor kurang dapat merencanakan dan menerapkan prosedur audit yang tepat.

Penelitian lain terkait klien baru dilakukan oleh Carcello \& Nagy (2004). Penelitian tersebut 
dilakukan dengan menggunakan sampel sebanyak 68.342 perusahaan ( 147 perusahaan melakukan fraud dan 68.195 perusahaan tidak melakukan fraud) selama 13 tahun sejak tahun 1988 sampai dengan tahun 2000 dengan menggunakan regresi logistik. Penelitian tersebut bertujuan untuk mengetahui hubungan antara tenur audit KAP dengan pelanggaran pelaporan keuangan yang disengaja (fraudulent financial reporting). Hasil penelitian tersebut menunjukkan bahwa pelanggaran pelaporan keuangan yang disengaja banyak terjadi pada periode awal hubungan antara auditor dengan klien (terutama tiga tahun pertama) dan paling banyak terjadi pada perikatan audit tahun pertama yaitu pada klien baru. Lebih lanjut, Carcello \& Nagy (2004,p. 58) mengutip pernyataan BDO Seidman (2003) menyatakan defisiensi audit akan meningkat pada perikatan audit tahun pertama karena auditor belum familiar dengan bisnis, operasi, sistem, kontrol, dan kebijakan akuntansi klien. Oleh karena itu, hipotesis pertama penelitian ini adalah: Oleh karena itu, hipotesis pertama penelitian ini adalah:

$\mathrm{H}_{2}$ : Klien baru berpengaruh terhadap defisiensi audit yang diidentifikasi PPPK.

Penelitian terkait dengan ukuran perusahaan yang diaudit (ukuran klien) dilakukan oleh Hermanson, Houston, \& Rice, (2007). Penelitian tersebut menyimpulkan perusahaan yang lebih kecil, diukur dari total aset perusahaan, mempunyai peluang terjadinya defisiensi audit yang lebih banyak. Penelitian lain dilakukan oleh Febriyanti \& Mertha (2014). Penelitian tersebut menggunakan analisis regresi logistik dengan sampel sebanyak 112 perusahaan manufaktur yang terdaftar di Bursa Efek Indonesia. Penelitian tersebut menyatakan bahwa ukuran perusahaan klien berpengaruh positif signifikan terhadap kualitas audit.

Kafabih \& Adiwibowo (2017) menggunakan analisis regresi linear berganda terhadap sampel 146 perusahaan manufaktur yang terdaftar di Bursa Efek Indonesia. Penelitian tesebut juga memberikan kesimpulan serupa dengan dua penelitian sebelumnya yaitu ukuran perusahaan klien berpengaruh positif signifikan terhadap kualitas audit yang artinya semakin besar ukuran klien, maka kemungkinan defisiensi audit akan semakin kecil sehingga dapat diartikan semakin kecil ukuran klien, maka kemungkinan terjadinya defisiensi audit akan semakin banyak. Oleh karena itu, hipotesis pertama penelitian ini adalah:
$\mathrm{H}_{3}$ : Ukuran klien berpengaruh terhadap defisiensi audit yang diidentifikasi PPPK.

Penelitian ini menggunakan variabel kontrol berupa klien yang diregulasi oleh regulator (regulated client). Hal ini mengacu kepada penelitian Chang et al. (2017) tentang pengaruh beban kerja auditor terhadap defisiensi audit yang diidentifikasi PCAOB yang menyatakan bahwa klien regulated indusrtry memiliki potensi terjadinya defisiensi audit yang lebih kecil. Regulated client dalam penelitian ini meliputi perusahaan terbuka yang terdaftar di Bursa Efek Indonesia serta perusahaan di bidang jasa keuangan yang meliputi bank, asuransi, lembaga pembiayaan, dan dana pensiun.

\section{METODE PENELITIAN}

Penelitian ini menggunakan data hasil pemeriksaan terhadap akuntan publik oleh PPPK tahun 2013-2016. Data lain yang digunakan adalah data klien AP dan data laporan tahunan KAP yang diterbitkan oleh PPPK.

Sampel penelitian dalam penelitian ini dipilih dengan menggunakan teknik purposive sampling. Kriteria pemilihan sampel adalah 1) Akuntan publik telah diperiksa oleh PPPK selama tahun 2013-2016 terkait aspek perikatan audit umum atas laporan keuangan melalui pemeriksaan berkala dan laporan hasil pemeriksaannya telah diterbitkan secara lengkap. 2) Seluruh data yang diperlukan terkait dengan jumlah temuan hasil pemeriksaan PPPK, jumlah klien akuntan publik yang diperiksa selama satu tahun, data perikatan tahun pertama bagi akuntan publik, total aset perusahan klien yang dijadikan sampel pemeriksaan PPPK, serta jenis bidang usaha yang dijalankan oleh klien audit yang dijadikan sampel pemeriksaan PPPK tersedia secara lengkap.

Terkait dengan variabel penelitian, beban kerja akuntan publik (WORK) dilihat dari banyaknya jumlah klien yang harus ditangani oleh seorang akuntan publik dalam satu tahun (Setiawan W \& Fitriany, 2011). Oleh karena kondisi pemeriksaan akuntan publik di Indonesia dilakukan dengan cara sampel sehingga tidak semua AP dalam suatu KAP diperiksa, maka beban kerja akuntan publik (WORK) dalam penelitian ini diukur dengan banyaknya jumlah klien audit umum atas laporan keuangan yang ditangani AP yang dijadikan sampel pemeriksaan perikatan audit dalam satu tahun berdasarkan laporan tahunan KAP. 
Klien baru (NEWCLNT) adalah klien yang baru pertama kali diaudit oleh AP yang diperiksa. Adanya klien baru ini mengharuskan dilakukannya pengujian saldo awal (Institut Akuntan Publik Indonesia, 2013b). Klien baru diukur dengan melihat tahun ke-n klien tersebut diaudit oleh akuntan publik yang dijadikan sampel pemeriksaan. Klien baru merupakan klien ke1 yang diperiksa oleh akuntan publik, sedangkan di luar itu merupakan klien berulang.

Ukuran klien (SIZECLNT) menunjukkan besar kecilnya ukuran perusahaan klien yang diaudit oleh AP. Ukuran klien dilihat dengan menggunakan logaritma natural total aset perusahaan klien sampel dari akuntan publik yang diperiksa oleh PPPK. Pengukuran ini mengacu kepada penelitian Setiawan \& Fitriany (2011) serta Cahan \& Sun (2015).

Defisiensi audit yang diidentifikasi oleh PPPK merupakan temuan hasil pemeriksaan berkala PPPK terhadap akutan publik terkait aspek perikatan audit umum atas laporan keuangan yang tercantum dalam laporan hasil pemeriksaan PPPK. Defisiensi audit dalam penelitian ini didefinisikan sebagai kegagalan auditor untuk secara keseluruhan memenuhi persyaratan dalam standar audit yang berlaku umum di Indonesia yaitu Standar Profesional Akuntan Publik. Dalam penelitian ini, defisiensi audit diukur dengan banyaknya jumlah temuan hasil pemeriksaan berkala PPPK terhadap akutan publik terkait aspek perikatan audit umum atas laporan keuangan yang dinyatakan dalam laporan hasil pemeriksaan PPPK. Pengukuran ini mengacu kepada hasil penelitian Kang et al. (2014).

Variabel kontrol yang digunakan dalam penelitian ini adalah klien yang termasuk dalam perusahaan yang diawasi oleh regulator (klien regulated industry). Perusahaan tersebut meliputi perusahaan terbuka yang terdaftar di Bursa Efek Indonesia serta perusahaan di bidang jasa keuangan yang meliputi bank, asuransi, lembaga pembiayaan, dan dana pensiun. Hal ini mengacu kepada penelitian Chang et al. (2017). Hasil penelitian tersebut menyatakan bahwa klien regulated industry memiliki potensi terjadinya defisiensi audit yang lebih kecil dibandingkan dengan klien yang tidak termasuk ke dalam regulated industry.

Di samping itu, menurut hasil penelitian Maletta \& Wright (1996) perusahaan yang termasuk dalam regulated industries memiliki tingkat kesalahan dalam laporan keuangan lebih sedikit serta terdapat lebih banyak kesalahan yang dapat dideteksi melalui prosedur audit dibandingkan dengan perusahaan yang tidak termasuk dalam regulated industries. Penyebabnya adalah regulasi dan pengawasan yang dilaksanakan oleh regulator akan membantu perusahaan yang termasuk dalam regulated industries untuk dapat menciptakan pengendalian internal yang lebih baik. Klien yang termasuk dalam regulated industry merupakan data dummy, dimana klien diberi angka 1 jika termasuk dalam regulated industries yaitu perusahaan terbuka yang terdaftar di Bursa Efek Indonesia dan perusahaan di bidang jasa keuangan yang meliputi bank, asuransi, lembaga pembiayaan, dan dana pensiun, sedangkan angka 0 diberikan jika klien tidak termasuk dalam regulated industries (nonregulated client).

Adapun model penelitian adalah sebagai berikut. $D E F=\alpha_{0}+\beta_{1}$ WORK $_{i}+\beta_{2} N E W C L N T_{i}+$

Keterangan:

$$
\beta_{3} \text { SIZECLNT }_{i}+\beta_{4} R E G C L N T+\varepsilon_{i}
$$

$D E F \quad=$ Defisiensi audit yang diidentifikasi PPPK diukur dengan banyaknya jumlah temuan hasil pemeriksaan berkala PPPK terhadap akutan publik terkait aspek perikatan audit umum atas laporan keuangan yang dinyatakan dalam laporan hasil pemeriksaan PPPK.

WORK = Beban kerja akuntan publik diukur dengan banyaknya jumlah klien audit umum atas laporan keuangan yang ditangani akuntan publik yang diperiksa oleh PPPK selama satu tahun berdasarkan laporan tahunan KAP.

$N E W C L N T=$ Klien baru diukur dengan melihat tahun ke-n klien tersebut diaudit oleh akuntan publik yang dijadikan sampel pemeriksaan oleh PPPK. Klien baru merupakan klien yang diperiksa oleh akuntan publik pada tahun ke-1, sedangkan diluar itu merupakan klien berulang.

SIZECLNT = Ukuran perusahaan klien (ukuran klien) yang diaudit diukur dengan menggunakan logaritma natural total aset perusahaan klien yang dijadikan sampel pemeriksaan oleh PPPK.

REGCLNT $=$ Klien yang diregulasi meliputi perusahaan terbuka yang terdaftar di Bursa Efek Indonesia serta perusahaan di bidang jasa keuangan yang meliputi bank, asuransi, lembaga pembiayaan, dan dana pensiun. 
Variabel ini merupakan data dummy, yang mana diberi angka 1 jika merupakan klien yang diregulasi dan 0 jika bukan merupakan klien yang diregulasi.

$\alpha \quad=$ Konstanta

$\beta \quad=$ Koefisien regresi

$\varepsilon \quad=$ Error

Penelitian ini menggunakan teknik analisis regresi linear berganda. Sebelum dianalisis, dilakukan uji asumsi klasik terlebih dahulu yang terdiri dari uji multikoleniaritas, uji autokorelasi, uji heteroskedastisitas, dan uji normalitas. Selanjutnya dilakukan analisis regresi dengan metode ordinary least square (OLS) dan menilai goodness of fit model penelitian dengan melihat koefisien determinasi (adjusted $\mathrm{R}^{2}$ ), uji statistik F, dan uji statistik t (Ghozali, 2013). Tingkat keyakinan yang digunakan dalam penelitian ini adalah sebesar 95\% dengan standard error (a) sebesar 5\%.

\section{HASIL DAN PEMBAHASAN}

Pendeskripsian data penelitian dilakukan dengan menggunakan analisis statistik deskriptif. Setiap variabel baik dependen, independen, maupun variabel kontrol akan dilihat nilai terendahnya (minimum), nilai tertingginya (maximum), jangkauannya (range), rata-ratanya (mean), dan standar deviasinya (standard deviation). Adapun hasil dari analisis statistik deskriptif untuk tiap-tiap variabel dapat dilihat pada Tabel 2.
Berdasarkan Tabel 2 dapat dilihat bahwa jumlah sampel adalah sebanyak 184 AP. Variabel beban kerja akuntan publik (WORK) memiliki nilai minimum 1 yang artinya beban kerja terkecil bagi seorang akuntan publik yang diperiksa PPPK dalam satu tahun adalah sebanyak satu klien audit. Adapun nilai maksimum sebesar 249 menunjukkan beban kerja terberat yang dipikul seorang akuntan publik yang diperiksa PPPK dalam satu tahun adalah sebanyak 249 klien audit.

Variabel klien baru (NEWCLNT) menunjukkan nilai minimum 1 dan nilai maksimum sebesar 4 . Nilai 1 menunjukkan bahwa klien tersebut merupakan klien yang baru pertama kali diperiksa oleh akuntan publik yang dijadikan sampel pemeriksaan sehingga merupakan klien baru. Adapun untuk nilai selain 1, maka klien tersebut merupakan klien berulang. Nilai maksimum 4 menunjukkan waktu paling lama suatu klien ditangani akuntan publik yang diperiksa PPPK adalah selama 4 tahun berturut-turut.

Variabel SIZECLNT menunjukkan nilai terendah sebesar 21,62 dan nilai tertinggi sebesar 33,84 dengan jangkauan (range) sebesar 12,22. Nilai minimum sebesar 21,62 menunjukkan bahwa nilai logaritma natural terendah dari aset klien adalah 21,62 dan nilai tertingginya sebesar 33,84.

Variabel kontrol klien yang diregulasi (REGCLNT) menunjukkan nilai terendah sebesar 0 dan nilai terbesar adalah 1 . Penyebabnya karena variabel klien yang diregulasi merupakan variabel

Tabel 2. Hasil Statistik Deskriptif

\begin{tabular}{crrrrrr}
\hline Variabel & N & Range & Minimum & Maximum & Mean & $\begin{array}{c}\text { Std. } \\
\text { Deviation }\end{array}$ \\
\hline WORK & 184 & 248,00 & 1,00 & 249,00 & 37,12 & 41,24 \\
NEWCLNT & 184 & 3,00 & 1,00 & 4,00 & 1,76 & 0,85 \\
SIZECLNT & 184 & 12,22 & 21,62 & 33,84 & 27,25 & 2,29 \\
REGCLNT & 184 & 1,00 & 0,00 & 1,00 & 0,38 & 0,48 \\
DEF & 184 & 13,00 & 0,00 & 13,00 & 4,16 & 3,02 \\
\hline Sumber: Data diolah, 2018 & & & & &
\end{tabular}

dummy yang diberi kode 1 jika klien yang diaudit oleh akuntan publik merupakan klien yang diregulasi, sedangkan kode 0 diberikan untuk klien yang tidak diregulasi.

Variabel dependen defisiensi audit yang diidentifikasi PPPK $(D E F)$ memiliki nilai terendah sebesar 0 dan nilai tertinggi sebesar 13. Nilai terendah 0 berarti bahwa akuntan publik telah seluruhnya taat terhadap Standar Profesional Akuntan Publik, sedangkan nilai maksimum 13 menunjukkan bahwa jumlah temuan terbanyak atas akuntan publik yang diperiksa PPPK adalah 13 temuan.

Selanjutnya, sebelum melakukan pengujian hipotesis, terlebih dahulu dilakukan uji asumsi klasik. Uji multikoleniaritas dilakukan dengan melihat nilai tolerance dan variance inflation factor (VIF) 
berdasarkan output regresi. Hasil pengujian untuk tiap-tiap variabel independen diperoleh nilai tolerance di atas 0,10 dan VIF nya kurang dari 10 sehingga disimpulkan tidak terjadi multikoleniaritas dalam model regresi.
Uji heteroskedastisitas dilakukan dengan menggunakan dua cara yaitu dengan melihat grafik plot dan melakukan uji Park. Tampilan hasil pengujian dengan grafik plot adalah sebagaimana tampak pada Gambar 1.

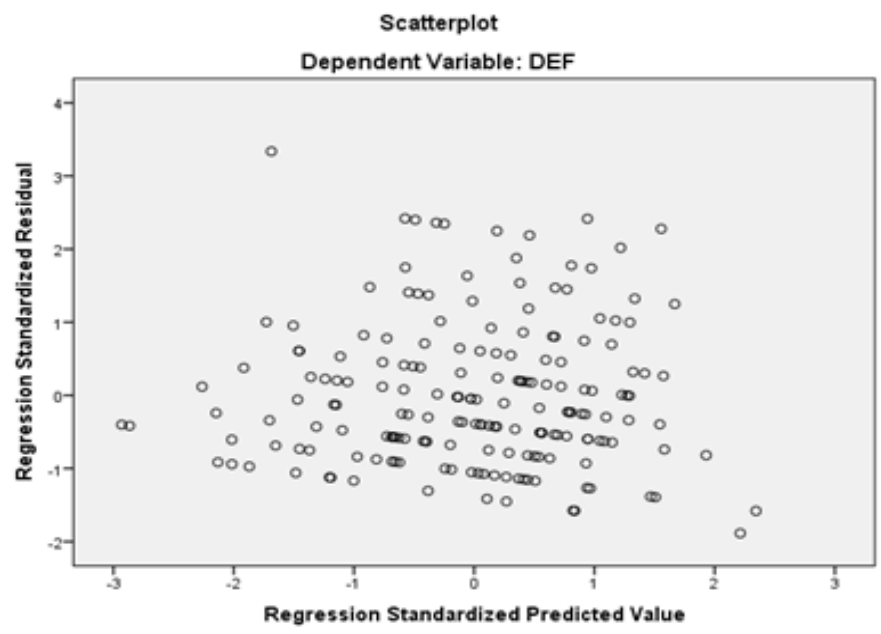

Gambar 1. Hasil Uji Heteroskedastisitas dengan Grafik Plot

Sumber: Output regresi dengan IBM SPSS 24, 2018

Pada Gambar 1 terlihat titik-titik yang ada menyebar di atas dan di bawah angka 0 pada sumbu $\mathrm{Y}$ dengan pola yang tidak jelas sehingga disimpulkan bahwa tidak terjadi heteroskedastisitas. Untuk mengonfirmasi hasil pengujian tersebut, dilakukan uji Park dengan melakukan regresi menggunakan logaritma dari kuadrat residual sebagai variabel dependen dengan hasil bahwa koefisien parameter beta di atas 0,05 sehingga disimpulkan bahwa dalam model regresi tidak terdapat heteroskedastisitas.

Uji normalitas dilakukan dengan uji KolmogorovSmirnov. Hasil uji menunjukkan bahwa besarnya test statistic Kolmogorov-Smirnov adalah sebesar 0,101 dan signifikan pada 0,05 (nilai sig. sebesar 0,000 ) yang artinya data residual berdistribusi normal.
Uji autokorelasi dilakukan dengan uji DurbinWatson. Nilai DW yang diperoleh adalah sebesar 1,928. Menurut tabel DW, untuk jumlah observasi (n) sebanyak 183 dengan empat variabel independen $(\mathrm{k}=4)$, maka nilai $\mathrm{dL}=1,7137$, sedangkan $\mathrm{dU}=$ 1,8029. Oleh karena nilai d berada di antara dU dan (4-dU) yaitu 1,8029<1,928<2,1971, maka disimpulkan bahwa H0 diterima yang artinya tidak terdapat autokorelasi dalam model regresi.

Setelah seluruh uji asumsi klasik terpenuhi, maka model regresi dinyatakan valid sehingga dapat dilakukan regresi berganda dengan metode ordinary least squares (OLS). Adapun hasil regresi adalah seperti tampak pada Tabel 3.

Tabel 3 . Koefisien Regresi Berganda

\begin{tabular}{|c|c|c|c|c|c|}
\hline \multirow[b]{2}{*}{ Model } & \multicolumn{2}{|c|}{$\begin{array}{l}\text { Unstandardized } \\
\text { Coefficients }\end{array}$} & \multirow{2}{*}{$\begin{array}{l}\text { Standardized } \\
\text { Coefficients } \\
\text { Beta }\end{array}$} & \multirow[b]{2}{*}{$\mathrm{t}$} & \multirow{2}{*}{ Sig. } \\
\hline & $\mathrm{B}^{\mathrm{Co}}$ & $\begin{array}{l}\text { cients } \\
\text { Std. Error }\end{array}$ & & & \\
\hline WORK & $-0,007$ & 0,005 & $-0,078$ & $-1,200$ & 0,232 \\
\hline NEWCLNT & $-0,098$ & 0,253 & $-0,036$ & $-0,387$ & 0,700 \\
\hline SIZECLNT & 0,167 & 0,021 & 0,794 & 7,842 & 0,000 \\
\hline REGCLNT & $-0,228$ & 0,452 & $-0,032$ & $-0,505$ & 0,614 \\
\hline Adjusted R Square & 0,490 & & & & \\
\hline $\mathrm{F}$ & 44,911 & & & & \\
\hline Sig. &, 000 & & & & \\
\hline
\end{tabular}

a. Dependent Variable: DEF

Sumber: Output regresi dengan IBM SPSS 24, 2018 
Berdasarkan Tabel 3 diketahui bahwa model memiliki nilai adjusted $R$ square sebesar 0,490 yang artinya $49,0 \%$ variasi dari variabel defisiensi audit yang diidentifikasi PPPK dapat dijelaskan oleh variabel beban kerja akuntan publik (WORK), klien baru (NEWCLNT), ukuran klien (SIZECLNT), dan klien yang diregulasi (REGCLNT), sedangkan sisanya sebesar $51,0 \%$ dijelaskan oleh variabel lain yang tidak diteliti.Untuk hasil uji statistik F nilai signifikansinya kurang dari 0,05 maka model layak untuk digunakan untuk melakukan pengujian.

Berdasarkan output regresi pada Tabel 3, diketahui bahwa hanya variabel ukuran klien (SIZECLNT) yang berpengaruh terhadap defisiensi audit yang diidentifikasi PPPK. Hal ini terlihat dari nilai nilai signifikansi sebesar 0,000. Dengan demikian, maka persamaan model regresi adalah sebagai berikut:

\section{$D E F=-0,07 W O R K-0,098 N E W C L N T+0,167 S I Z E C L N T$ $-0,228 R E G C L N T$}

Berdasarkan output regresi pada Tabel 3, variabel beban kerja akuntan publik (WORK) memiliki tingkat signifikansi sebesar 0,232 (lebih dari 0,05) sehingga disimpulkan variabel beban kerja akuntan publik tidak berpengaruh terhadap defisiensi audit yang diidentifikasi PPPK. Hal ini menunjukkan bahwa jumlah klien yang ditangani oleh akuntan publik dalam satu tahun yang digunakan sebagai pengukuran untuk beban kerja akuntan publik tidak berpengaruh terhadap defisiensi audit yang diidentifikasi PPPK. Hasil penelitian ini berbeda dengan hasil penelitian Chang et al.(2017) dan Setiawan \& Fitriany, (2011) yang menyatakan bahwa beban kerja berpengaruh positif terhadap terjadinya defisiensi audit.

Penyebab hal tersebut diduga karena akuntan publik tetap berusaha untuk menjaga reputasinya ((Deis \& Giroux, 1992) dan (Linda Elizabeth DeAngelo, 1981) meskipun memiliki jumlah klien yang banyak. Akuntan publik berusaha menjaga agar reputasinya tetap baik di mata klien dengan maksud agar dapat memperoleh klien baru dan mempertahankan klien lama. Oleh karena itu, meskipun beban kerjanya tinggi, tidak membuat akuntan publik menurunkan sikap skeptisme profesionalnya baik dalam tahap perencanaan, pelaksanaan, maupun pelaporan audit.

Selain itu, kemungkinan penyebab lainnya adalah akuntan publik tetap memperhatikan kualitas auditnya meskipun memiliki jumlah klien yang banyak karena mengetahui bahwa hasil pekerjaannya akan direviu oleh pihak ketiga (seperti oleh PPPK) dan pihak ketiga tersebut dapat memberikan sanksi yang tegas bagi akuntan publik terkait (Deis \& Giroux, 1992). Dengan demikian, akuntan publik akan berusaha untuk mematuhi standar profesional yang berlaku dalam pelaksanaan auditnya untuk menghindari sanksi dari pereviu tersebut. Lebih lanjut, reviu dari pihak ketiga tersebut dapat meningkatkan kekuatan akuntan publik dalam menghadapi tekanan dari klien yang dapat berpotensi menurunkan kualitas audit (Deis \& Giroux).

Kemungkinan lain penyebab tidak berpengaruhnya beban kerja akuntan publik terhadap defisiensi audit yang diidentifikasi PPPK adalah karena akuntan publik didukung oleh tim audit yang kompeten. Tim audit yang kompeten tersebut mempunyai kemampuan untuk merencanakan audit dengan baik, memiliki pengetahuan dan pengalaman yang memadai, serta dapat melakukan supervisi/reviu secara memadai (Halim, Rosidi, \& Achsin, 2014). Keberadaan tim audit yang kompeten tersebut dapat mempermudah proses supervisi sehingga supervisi dapat berjalan secara efektif dan efisien. Menurut Standar Audit 220 tentang Pengendalian Mutu untuk Audit atas Laporan Keuangan, akuntan publik bertanggung jawab untuk melakukan supervisi atas pelaksanaan perikatan sesuai dengan standar profesi dan ketentuan peraturan perundang-undangan yang berlaku. Manfaat dari supervisi tersebut adalah untuk mengurangi variasi dari judgment (Trotman \& Yetton, 1985). Di samping itu, supervisi juga dapat meningkatkan akurasi dari prereview judgment (Trotman \& Yetton, 1985). Oleh karena itu, meskipun akuntan publik memiliki beban kerja yang tinggi, hasil auditnya secara umum tidak menunjukkan perbedaan dengan akuntan publik yang memiliki beban kerja yang lebih rendah.

Berdasarkan output regresi pada Tabel 3, variabel klien baru (NEWCLNT) memiliki tingkat signifikansi sebesar 0,700 (lebih dari 0,05 ) sehingga disimpulkan variabel klien baru tidak berpengaruh terhadap defisiensi audit yang diidentifikasi PPPK. Hasil penelitian ini berbeda dengan hasil penelitian Liu et al. (2017), Carcello \& Nagy (2004), dan BDO 
Seidman (2003) dalam (Carcello \& Nagy, 2004) menyatakan bahwa audit klien baru dapat meningkatkan potensi terjadinya defisiensi audit dikarenakan keterbatasan pengetahuan auditor atas kondisi operasi, keuangan, serta kebijakan akuntansi klien sehingga menyebabkan auditor kurang dapat merencanakan dan menerapkan prosedur audit secara memadai.

Penyebab hal tersebut diduga karena independensi auditor pada klien baru lebih tinggi dibandingkan pada klien berulang ((Deis \& Giroux, 1996); (Dopuch, King, \& Schwartz, 2001); dan (Raiborn, Schorg, \& Massoud, 2006)). Pada klien berulang, auditor akan berusaha untuk mempertahankan klien tersebut sehingga auditor cenderung lebih mudah untuk menyetujui isu-isu pelaporan keuangan yang dapat mempengaruhi keandalan laporan keuangan klien (Raiborn et al., 2006). Disamping itu, auditor pada klien berulang memiliki insentif bisnis yang tinggi untuk mendapatkan penilaian baik dari klien sehingga termotivasi tinggi untuk lebih mudah menerima akunakun klien (Bazerman, Loewenstein, \& Moore, 2002). Hal tersebut tidak terjadi pada klien baru karena pada klien baru auditor menjadi lebih independen, baik secara kenyataan maupun penampilan, sehingga dapat lebih aktif untuk tidak menyetujui praktik akuntansi klien yang dipertanyakan (Raiborn et al., 2006). Dengan demikian, pada klien baru, auditor dapat merencanakan dan menerapkan prosedur audit secara lebih efektif dan efisien untuk dapat menemukan kesalahan dan/atau kecurangan yang dilakukan klien.

Penyebab lainnya diduga karena audit pada klien baru merupakan faktor kunci bagi auditor untuk memperoleh informasi apakah sebaiknya akan mempertahankan klien tersebut untuk periode berikutnya ataukah menghentikan auditnya hanya pada audit tahun pertama (Liu et al., 2017). Oleh karena itu, auditor akan melakukan upaya terbaiknya dalam melakukan audit pada tahun pertama untuk mengurangi potensi risiko pada tahun-tahun berikutnya.

Berdasarkan output regresi pada Tabel 3, variabel ukuran klien (SIZECLNT) memiliki nilai koefisien beta sebesar $+0,167$ dengan tingkat signifikansi sebesar 0,000 (kurang dari 0,05) sehingga disimpulkan bahwa variabel ukuran klien berpengaruh terhadap defisiensi audit yang diidentifikasi PPPK. Arah dari pengaruh tersebut adalah positif yang artinya semakin besar ukuran klien yang diukur dengan logaritma natural dari total aset klien, maka defisiensi audit yang diidentifikasi PPPK menjadi semakin banyak. Hasil penelitian ini bertentangan dengan hasil penelitian (Hermanson et al., 2007) yang menyimpulkan bahwa perusahaan yang lebih kecil, memiliki peluang defisiensi audit yang lebih banyak. Hasil penelitian ini juga bertentangan dengan hasil penelitian Febriyanti \& Mertha (2014), Nindita \& Siregar (2012), serta Kafabih \& Adiwibowo (2017) yang menyatakan bahwa perusahaan yang lebih besar akan memiliki peluang defisiensi audit yang lebih sedikit.

Namun demikian, hasil penelitian ini selaras dengan penelitian Lobo \& Zhou (2006) yang menyatakan bahwa perusahaan yang lebih besar memiliki peluang terjadinya defisiensi audit yang lebih banyak. Perusahaan besar memiliki peluang untuk melakukan kesalahan dan/atau kecurangan yang lebih banyak sebab memiliki kompleksitas operasi yang lebih tinggi sehingga pengguna eksternal sulit untuk mendeteksi kesalahan dan/atau kecurangan tersebut. Dengan demikian, prosedur audit yang diterapkan oleh auditor selaku pihak eksternal dapat gagal untuk mendeteksi adanya kesalahan dan/atau kecurangan yang terjadi.

Berdasarkan output regresi pada Tabel 3, variabel kontrol berupa klien yang diregulasi oleh regulator (REGCLNT) memiliki tingkat signifikansi sebesar 0,614 (lebih dari 0,05) sehingga disimpulkan bahwa variabel klien yang diregulasi oleh regulator (regulated client) tidak berpengaruh terhadap defisiensi audit yang diidentifikasi PPPK.

Hasil tersebut berbeda dengan hasil penelitian Chang et al. (2017) yang menyatakan bahwa regulated client memiliki potensi terjadinya defisiensi audit yang lebih kecil dibandingkan dengan nonregulated client. Hasil ini juga berbeda dengan hasil penelitian Maletta \& Wright (1996) yang menyatakan bahwa perusahaan yang termasuk dalam regulated industries memiliki tingkat kesalahan dalam laporan keuangan yang lebih sedikit serta lebih banyak kesalahan yang dapat dideteksi melalui prosedur audit dibandingkan dengan perusahaan yang tidak termasuk dalam regulated industries.

Penyebab hal tersebut diduga karena perusahaan yang diregulasi memiliki operasional bisnis yang lebih kompleks dibandingkan dengan nonregulated client baik untuk perusahaan terbuka yang terdaftar di Bursa Efek Indonesia ((Innayati \& Susilowati, 2015) dan (Darmiari \& Ulupui, 2014) maupun untuk 
perusahaan jasa keuangan yang meliputi perbankan, asuransi, dana pensiun, dan lembaga pembiayaan (Otoritas Jasa Keuangan, 2016). Akibatnya auditor selaku pihak eksternal kesulitan untuk mendeteksi kesalahan dan/atau kecurangan dalam penyajian dan pelaporan keuangan (Lobo \& Zhou, 2006). Oleh karena itu, meskipun pengawasan dari regulator dapat membantu regulated client menciptakan pengendalian internal yang lebih baik, namun kompleksitas operasional bisnis dari regulated client juga dapat menyebabkan auditor selaku pihak eksternal kesulitan untuk menemukan adanya kesalahan dan/atau kecurangan yang terjadi. Dengan demikian, risiko auditor tidak dapat mendeteksi salah saji dalam laporan keuangan relatif sama antara audit untuk regulated client dan nonregulated client.

\section{SIMPULAN}

Berdasarkan hasil penelitian dan pembahasan, disimpulkan bahwa beban kerja akuntan publik dan klien baru tidak berpengaruh terhadap defisiensi audit yang diidentifikasi PPPK sedangkan ukuran klien berpengaruh positif terhadap defisiensi audit yang diidentifikasi PPPK yang artinya semakin besar ukuran klien (yang ditunjukkan dengan logaritma natural total aset klien), maka jumlah defisiensi audit yang diidentifikasi PPPK akan semakin banyak. Hal ini disebabkan klien berukuran lebih besar memiliki kompleksitas operasi yang lebih tinggi sehingga berpeluang untuk melakukan kesalahan dan/atau kecurangan yang lebih banyak dibandingkan dengan klien yang lebih kecil sehingga sulit dideteksi oleh auditor selaku pihak eksternal.

Penelitian ini diharapkan dapat menjadi masukan bagi akuntan publik untuk memberikan perhatian yang tepat atas audit klien-klien besar sebab kompleksitas operasinya menimbulkan potensi kecurangan dan/atau kesalahan yang dihasilkan lebih tinggi dan lebih sulit untuk dideteksi auditor. Penelitian ini diharapkan juga dapat memberikan masukan bagi PPPK dalam menentukan sampel pemeriksaan terhadap akuntan publik setiap tahunnya dengan melihat karakteristik ukuran klien yang ditangani oleh akuntan publik.

Penelitian ini memiliki beberapa keterbatasan antara lain pengukuran defisiensi audit tidak mempertimbangkan bobot kualitas temuan, tidak dipertimbang kannya beban kerja akuntan publik yang berasal dari beban kerja non-audit, dan keterbatasan periode pemeriksaan akuntan publik yang digunakan.

\section{REFERENSI}

Bazerman, M. H., Loewenstein, G., \& Moore, D. A. (2002). Why good accountants do bad audits. Harvard Business Review, 80 (11), 97-102.

Cahan, S. F., \& Sun, J. (2015). The Effect of Audit Experience on Audit Fees and Audit Quality. Journal of Accounting, Auditing and Finance, 30(1), 78-100. https://doi.org/10.1177/ $0148558 X 14544503$.

Carcello, J. V., \& Nagy, A. L. (2004). Audit firm tenure and fraudulent financial reporting. Auditing: A Journal of Practice \& Theory, 23(2), 55-69.

Chang, C. J., Luo, Y., \& Zhou, L. (2017). Audit deficiency and auditor workload: Evidence from PCAOB triennially inspected firms. Review of Accounting and Finance. https://doi.org/ 10.1108/RAF-03-2017-0050.

Darmiari, N. P. D., \& Ulupui, I. G. K. A. (2014). Karakteristik Perusahaan di Bursa Efek Indonesia, Reputasi Kantor Akuntan Publik dan Ketepatwaktuan Pelaporan Keuangan. EJurnal Akuntansi Universitas Udayana, 9(1), $38-57$.

Deis, D. R., \& Giroux, G. A. (1992). Determinants of in Audit Sector Quality the Public. American Accounting Association, 67(3), 462-479.

Deis, D. R., \& Giroux, G. A. (1996). The effect of auditor changes on audit fees, audit hours, and audit quality. Journal of Accounting and Public Policy, 15(1), 55-76. https://doi.org/ 10.1016/0278-4254(95)00041-0.

Dopuch, N., King, R. R., \& Schwartz, R. (2001). An experimental investigation of retention and rotation requirements. Journal of Accounting Research. https://doi.org/10.1111/1475679X.00005.

Febriyanti, N. M. D., \& Mertha, M. I. (2014). Pengaruh masa perikatan audit, rotasi KAP, ukuran perusahaan klien, dan ukuran KAP pada kualitas audit. E-Jurnal Akuntansi Universitas Udayana.

Ghozali, I. (2013). Aplikasi Analisis Multivariate dengan Program IBM SPSS 23. Semarang: Badan Penerbit Universitas Diponegoro.

Halim, A., T, S., Rosidi, \& Achsin, M. (2014). Effect of competence and auditor independence on audit quality with audit time budget and professional commitment as a moderation variable. 
International Journal of Business and Management Invention.

Hermanson, D. R., Houston, R. W., \& Rice, J. C. (2007). PCAOB inspections of smaller CPA firms: Initial evidence from inspection reports. Accounting Horizons, 21(2), 137-152. https:// doi.org/10.2308/acch.2007. 21.2.137.

Innayati, C. D., \& Susilowati, E. (2015). Pengaruh karakteristik perusahaan dan auditor terhadap audit delay (studi kasus pada perusahaan hotel, restoran, dan pariwisata di Bursa Efek Indonesia). Jurnal Akuntansi, XIX(03), 449461.

Institut Akuntan Publik Indonesia. (2013a). Standar Audit 220: Pengendalian Mutu untuk Audit atas Laporan Keuangan. Jakarta: Salemba Empat.

Institut Akuntan Publik Indonesia. (2013b). Standar Audit 510: Perikatan Audit Tahun PertamaSaldo Awal. Jakarta: Salemba Empat.

Jensen, M. C., \& Meckling, W. H. (1976). Theory of the firm: Managerial behavior, agency cost and ownership structure. Journal of Financial Economics.

Kafabih, M., \& Adiwibowo, A. S. (2017). Analisis pengaruh client size, audit firm size, dan audit fee terhadap audit quality. Diponegoro Journal of Accounting, 6(3), 1-11.

Kang, F., Farag, M., Hurt, R., \& Wyrick, C. (2014). The association between PCAOB-identified audit deficiencies and small audit firms' characteristics: Evidence from PCAOB inspection reports. Managerial Auditing Journal, 29(8), 717-735. https://doi.org/ 10.1108/MAJ-12-2013-0975.

Linda Elizabeth DeAngelo. (1981). Auditor Size And Audit Quality. Journal of Accounting and Economics, 3 (1981)(North-Holland Publishing Company AUDITOR), 183-199. https://doi.org/ 10.1021/n10602701.

Liu, L. L., Xie, X., Chang, Y. S., \& Forgione, D. A. (2017). New clients, audit quality, and audit partner industry expertise: Evidence from
Taiwan. International Journal of Auditing. https://doi.org/10.1111/ijau.12095.

Lobo, G. J., \& Zhou, J. (2006). Did conservatism in financial reporting increase after the SarbanesOxley act? initial evidence. Accounting Horizons, 20 Number, 57-73. https://doi.org/ 10.2308/acch.2006. 20.1.57

Maletta, M., \& Wright, A. (1996). Audit Evidence Planning: An Examination of Industry Error Characteristics. Auditing: A Journal of Practice \& Theory (Vol. 15).

Nindita, C., \& Siregar, S. V. (2012). Analisis Pengaruh Ukuran Kantor Akuntan Publik Terhadap Kualitas Audit di Indonesia. Jurnal Akuntansi Dan Keuangan, 14(2), 91-104. https://doi.org/10.9744/jak.14.2.91-104.

Otoritas Jasa Keuangan. (2016). Master Plan Sektor Jasa Keuangan Indonesia 2015-2019. Retrieved from http://www.ojk. go.id/id/berita-dankegiatan/publikasi/Documents/Pages/Masterplan-sektor-jasa-keuangan-indonesia-periode2015-2019/MPSJKI OJK Final_Ind.pdf.

Public Company Accounting Oversight Board. (2006). 2005 Annual Report. Washington, D.C.

Public Company Accounting Oversight Board. (2016). Report on 2015 inspection of KPMG LLP (Headquartered in New York, New York). Washington, D.C.

Public Company Accounting Oversight Board. (2017). 2016 Annual Report. Washington, D.C.

Raiborn, C., Schorg, C. A., \& Massoud, M. (2006). Should auditor rotation be mandatory? Journal of Corporate Accounting \& Finance, 17(4), 37-49. https://doi.org/10.1002/jcaf.20214.

Setiawan W, L., \& Fitriany. (2011). Pengaruh Workload Dan Spesialisasi Auditor Terhadap Kualitas Audit Dengan Kualitas Komite Audit Sebagai Variabel Pemoderasi. Jurnal Akuntansi Dan Keuangan Indonesia, 8(1), 36-53.

Trotman, K. T., \& Yetton, P. W. (1985). The effect of the review process on auditor judgments. Journal of Accounting Research, 23(1), 256267. https://doi.org/10.2307/2490918. 